\title{
Small-scale clinal variation, genetic diversity and environmental heterogeneity in the marine gobies Pomatoschistus minutus and $P$. Iozanoi (Gobiidae, Teleostei)
}

\author{
ES Gysels, V Leentjes, and FAM Volckaert \\ Laboratory of Aquatic Ecology, Katholieke Universiteit Leuven, Ch. de Bériotstraat 32, B-3000 Leuven, Belgium
}

\begin{abstract}
Genetic variation was assayed at 14 allozyme loci in estuarine, coastal and offshore samples of lozano's goby, Pomatoschistus lozanoi and the sand goby, $P$. minutus. Samples were taken from locations on the Belgian Continental Shelf and in the Schelde estuary with a range of environmental heterogeneity. We evaluate whether any differences in (1) the degree of genetic variation and (2) allele frequencies at the various loci exist within samples occurring in various habitats on the BCS and in the Schelde estuary. No significant differences in levels of genetic
\end{abstract}

diversity were recorded between estuarine, coastal and offshore samples in either species. A temporally stable clinal gradient in allele frequencies at the two-allele locus GPI- $A^{*}$ was observed in $P$. lozanoi, differentiating the samples in an estuarine, coastal and offshore group. We suggest that these differences might be maintained by balancing selection at locus GPI-A*.

Heredity (2004) 93, 208-214, advance online publication, 23 June 2004; doi:10.1038/sj.hdy.6800496

Keywords: allozymes; environmental heterogeneity; gobies; Belgian Continental Shelf

\section{Introduction}

The adaptive significance of allozymatic polymorphisms has been the subject of a heated debate for years, until it waned in the early 1990s with the advance of DNA techniques (Hey, 1999). Allozyme-based population surveys had revealed high levels of polymorphism with no detectable effects on the phenotype of the organisms, suggesting that the majority of the variation found at the molecular level was selectively neutral (Kimura, 1979). DNA data at first seemed to confirm this hypothesis, with noncoding DNA evolving much faster and containing a higher amount of variability than coding regions. But while this neutral theory of evolution continues to provide a useful null hypothesis against which to test population genetic differentiation, genetic studies of natural populations have yielded convincing evidence that a number of polymorphisms are probably maintained by natural selection at the level of allozymes (Eanes, 2002 and references herein), as well as DNA markers (Ballard and Kreitman, 1995). Both large- and small-scale gradients in allele frequencies have been reported for a wide range of organisms (eg Koehn et al, 1983 and references herein), suggesting environmental selection pressure, with variability in temperature and (for marine species) salinity being considered as main selective agents.

Correspondence: ES Gysels, Laboratory of Aquatic Ecology, Katholieke Universiteit Leuven, Ch. de Bériotstraat 32, B-3000 Leuven, Belgium. E-mail:els.gysels@bio.kuleuven.ac.be

Received 13 March 2003; accepted 6 April 2004; published online 23 June 2004
Gobies of the genus Pomatoschistus (Gill) are among the most abundant fish species along the northeastern Atlantic coasts and have been widely used in ecological, evolutionary and behavioural studies (Fonds, 1973; Pampoulie et al, 1999; Jones et al, 2001). An electrophoretic survey of Atlantic and Mediterranean members of the genus Pomatoschistus occurring in habitats with a different degree of heterogeneity showed a positive correlation between the level of genetic variation within species and the degree of heterogeneity of the habitat in which each species preferentially occurs (Wallis and Beardmore, 1984a). In this study, we present the results of an allozyme survey of two of these species, the sand goby, Pomatoschistus minutus (Pallas, 1770) and lozano's goby, P. lozanoi (de Buen, 1923), carried out on the Belgian Continental Shelf (BCS) and in the Schelde estuary. These two gobies are closely related and show a similar mode of reproduction. During the breeding season males of either species display nuptial colours, territorial behaviour, nestbuilding and nest-guarding behaviour. After hatching the larvae are swept out of the nest and drift in the plankton for about a month before settling down for a demersal lifestyle (Fonds, 1973). P. minutus is more of a generalist in its habitat and food choice than P. lozanoi (Hamerlynck and Cattrijsse, 1994), and also has the broadest distribution, occurring in estuaries, coastal areas and offshore. (Miller, 1986). $P$. lozanoi is more neritic (Fonds, 1973), although at times large numbers occur in estuaries as well (Claridge et al, 1985; Maes et al, 1998). Wallis and Beardmore (1984a) reported significantly lower levels of heterozygosity in $P$. lozanoi than in its estuarine-marine relative $P$. minutus, 
but it was unclear whether this could be explained by either heterozygote advantage or else diversifying selection. If habitat heterogeneity promotes overall levels of polymorphism, then we expect populations of a species occurring in a heterogeneous environment to show higher levels of genetic diversity than those inhabiting more stable environments (Powell, 1971). Alternatively, a single locus under selection might show differences in allele frequencies as expected under the multiple niche model of balancing selection (Levene, 1953), when comparing populations across a heterogeneous environment subjected to differential selection pressure. Such a heterogeneous environment exists on the BCS, situated in the Southern Bight of the North Sea. The BCS is characterised by a system of several groups of sand banks alternating with gullies, which are continuously swept by strong tidal currents. A long-shore and inshore/offshore gradient under the influence of the highly turbid and heterogeneous Schelde estuary is reflected in a number of abiotic factors such as temperature, salinity, turbidity and nutrient concentrations (Nihoul and Hecq, 1984).

Hence, our aim is to assess possible effects of natural selection on the maintenance of genetic diversity and allele frequencies within two Pomatoschistus species occurring in a gradient of environmental heterogeneity. We evaluate whether any differences in (1) the degree of genetic variation and (2) allele frequencies at the various loci exist within samples occurring in various habitats on the BCS and in the Schelde estuary.

\section{Materials and methods}

\section{Sampling}

Sampling on the BCS was carried out with R/V 'Belgica' along an inshore/offshore gradient on the Coastal Banks (Stroombank), Flemish Banks (Kwintebank) as well as offshore banks (Bligh Bank, Noordhinder and Oosthinder). In addition, a number of governmental monitoring stations (MUMM stations) on the BCS were trawled. Fish were caught with a beam trawl (width: $3 \mathrm{~m}$ ) and an outer net mesh size of $20 \mathrm{~mm}$ stretched and a cod end mesh size of $12 \mathrm{~mm}$. The samples from the Schelde estuary were taken in Doel near the city of Antwerp at the cooling water intake of a nuclear power plant (Figure 1). Mesh size of the nets used was $4 \mathrm{~mm}$. For comparison a sample of Pomatoschistus lozanoi and P. minutus caught at the Frisian Front (North of the Wadden Sea) was subjected to allozyme electrophoresis as well.

\section{Allozyme electrophoresis}

The samples were frozen on dry ice or liquid nitrogen immediately after capture and kept in a $-80^{\circ} \mathrm{C}$ freezer until analysis. Gobies were identified morphologically on the basis of the dermal papillae of the head according to Miller (1986) and biochemically according to Wallis and Beardmore (1984b). As trawling in winter and spring yielded fewer gobies than during autumn, almost all fish from the winter samples were analysed, while a random subsample of Pomatoschistus sp caught in autumn was used. Liver, eye and muscle tissues were dissected and ground in 50-150 $\mu$ l of distilled water depending on the amount of tissue. The samples were

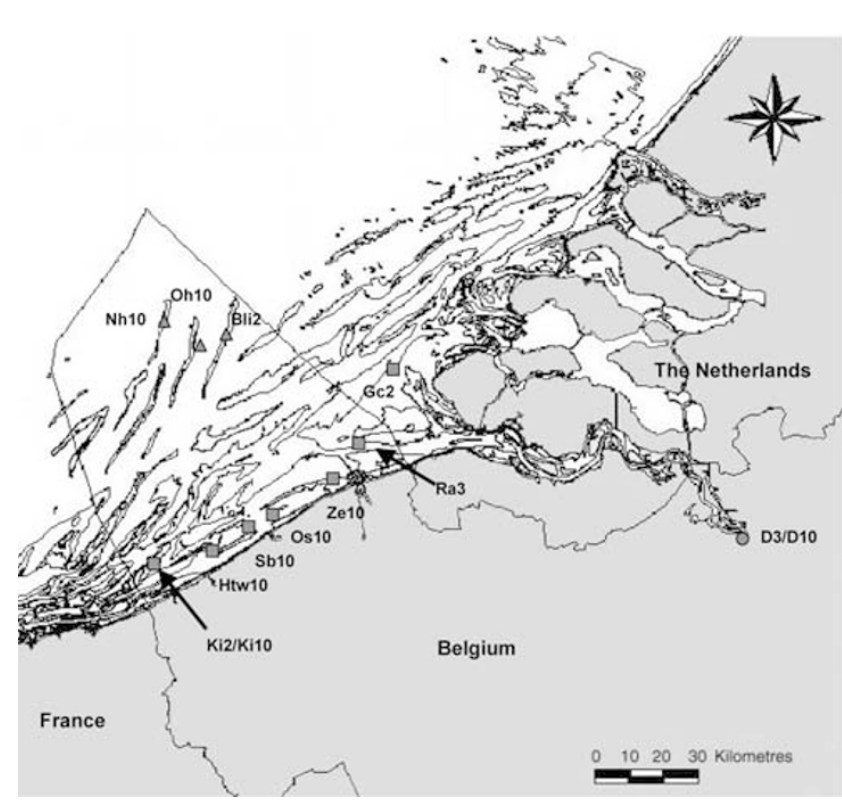

Figure 1 Sampling locations and codes of the sampling sites of $P$. minutus and P. lozanoi on the BCS and in the Schelde estuary. Triangles: offshore samples; Squares: coastal samples; Circle: estuarine sample. For the abbreviations, see Table 2.

subjected to cellulose acetate allozyme electrophoresis (Richardson et al, 1986). Two buffer systems were used: Tris-maleate $(\mathrm{pH}=7.8)$ and Tris-glycine $(\mathrm{pH}=8.8)$ as described by Hebert and Beaton (1989) (Table 1). Loci were stained according to recipes described by Hebert and Beaton (1989) and Richardson et al (1986). The slowest migrating locus was designated 1 or A according to the nomenclature of Shaklee et al (1990). The most common allele in $P$. minutus at each locus was called ' 100 ' and all the other alleles were classified according to their mobility relative to allele 100 of the locus under study.

\section{Data analysis}

Genetic diversity was estimated as observed and unbiased expected heterozygosity (Nei, 1978) and calculated in the GENETIX version 4.0. (Belkhir et al, 2001). A locus was considered polymorphic when the frequency of its most common allele did not exceed 0.99 in at least one sample. Samples were tested for linkage disequilibrium and deviations from Hardy-Weinberg proportions in the GENEPOP version 3.1 (Raymond and Rousset, 1995). $F_{\mathrm{ST}}$ values (Weir and Cockerham, 1984) were calculated in GENETIX and significance was assessed with permutation tests (1000 replicates). Multidimensional scaling analysis (MDSA) was applied on a matrix of pairwise $F_{\mathrm{ST}}$ values for both species in order to assess whether any geographical clustering of the samples could be found. Individual heterozygosity was computed as the number of heterozygous loci per individual. Samples were grouped into 'coastal', 'estuarine' and 'offshore' habitats (Figure 1, Table 2) to assess whether any significant differences in the level of heterozygosity could be found between habitats. A Kruskal-Wallis ANOVA was performed with the number of hetero- 
Table 1 P. minutus and P. lozanoi: summary of the 15 loci examined including the enzyme code (E.C.), the tissue collected and the buffer used to separate the alleles at the different loci

\begin{tabular}{|c|c|c|c|c|}
\hline Name & E.C. $n r$ & Locus & Tissue & Buffer \\
\hline \multirow[t]{3}{*}{ Lactate dehydrogenase } & \multirow[t]{3}{*}{ 1.1.1.27 } & $L D H-A^{*}$ & Eye, muscle & TM/TG \\
\hline & & $L D H-B^{*}$ & Eye & $\mathrm{TM} / \mathrm{TG}$ \\
\hline & & $\mathrm{LDH}-\mathrm{C}^{*}$ & Eye & $\mathrm{TM} / \mathrm{TG}$ \\
\hline \multirow{2}{*}{ Malate dehydrogenase } & \multirow{2}{*}{ 1.1.1.37 } & $M D H-A^{*}$ & Muscle & $\mathrm{TM}$ \\
\hline & & $M D H-B^{*}$ & Muscle & TM \\
\hline \multirow[t]{2}{*}{ Phosphoglucomutase } & \multirow[t]{2}{*}{ 2.7.5.1 } & $P G M-1^{*}$ & Eye, muscle & TM/TG \\
\hline & & PGM-2* & Eye, muscle & TM \\
\hline \multirow[t]{2}{*}{ Phosphoglucose isomerase } & \multirow[t]{2}{*}{ 5.3.1.9 } & GPI- $A^{*}$ & Eye, muscle & $\mathrm{TM} / \mathrm{TG}$ \\
\hline & & $G P I-B^{*}$ & Eye, muscle & TM/TG \\
\hline Isocitrate dehydrogenase & 1.1.1.42 & $I D H P-1^{*}$ & Muscle & $\mathrm{TM}$ \\
\hline Aspartate aminotransferase & 2.6.1.1 & $A A T^{*}$ & Muscle & $\mathrm{TM}$ \\
\hline Adenlyate kinase & 2.7.4.3 & $A K^{*}$ & Muscle & $\mathrm{TM}$ \\
\hline Creatine kinase & 2.7.3.2 & $C K-A^{*}$ & Muscle & TG \\
\hline Fumarate hydratase & 4.2.1.2 & $F H^{*}$ & Muscle & TM \\
\hline
\end{tabular}

$\mathrm{TM}=$ Tris-Maleate $(\mathrm{pH}=7.8)$ and $\mathrm{TG}=$ Tris-glycine $(\mathrm{pH}=8.8)$.

Table 2 P. minutus and P. lozanoi sampling sites on the sand banks of the BCS including code, period, coordinates and numbers of fish examined.

\begin{tabular}{|c|c|c|c|c|c|c|}
\hline Habitat & Sampling site & Code & Period & Longitude/latitude & Numbers of P. minutus & Numbers of P. lozanoi \\
\hline \multirow[t]{2}{*}{ Estuary } & Doel & D3 & March 1998 & $51^{\circ} 19.30 \mathrm{~N}$ & - & 34 \\
\hline & Doel & D10 & October 1998 & $\begin{array}{c}04^{\circ} 16.00 \mathrm{E} \\
51^{\circ} 19.30 \mathrm{~N} \\
04^{\circ} 16.00 \mathrm{E}\end{array}$ & 71 & - \\
\hline \multirow[t]{9}{*}{ Coast } & Kwintebank & Ki2 & February 1997 & $\begin{array}{l}51^{\circ} 17.61 \mathrm{~N} \\
02^{\circ} 38.92 \mathrm{E} \\
51^{\circ} 13.80 \mathrm{~N}\end{array}$ & 68 & - \\
\hline & Stroombank & $\mathrm{Sb}$ & February 1997 & $02^{\circ} 52.42 \mathrm{E}$ & 83 & - \\
\hline & Kwintebank & Ki10 & October 1997 & $\begin{array}{ll}51^{\circ} & 15.36 \mathrm{~N} \\
02^{\circ} & 38.34 \mathrm{E}\end{array}$ & 161 & 42 \\
\hline & 780 (Raan) & $\mathrm{Ra}$ & March 1997 & $\begin{array}{c}51^{\circ} 28.05 \mathrm{~N} \\
03^{\circ} 03.69 \mathrm{E}\end{array}$ & 50 & - \\
\hline & 702 (Zeebrugge) & $\mathrm{Ze}$ & October 1997 & $\begin{array}{l}51^{\circ} 22.63 \mathrm{~N} \\
03^{\circ} 18.68 \mathrm{E}\end{array}$ & - & 78 \\
\hline & 790 (Ostend) & Os & October 1997 & $\begin{array}{l}51^{\circ} 16.87 \mathrm{~N} \\
02^{\circ} 51.13 \mathrm{E}\end{array}$ & 52 & 50 \\
\hline & 120 & Htw & October 1998 & $\begin{array}{l}51^{\circ} 11.10 \mathrm{~N} \\
02^{\circ} 47.07 \mathrm{E}\end{array}$ & 35 & - \\
\hline & GC1 & Gc & February 1999 & $\begin{array}{l}51^{\circ} 34.40 \mathrm{~N} \\
03^{\circ} 24.80 \mathrm{E}\end{array}$ & - & 23 \\
\hline & 250 & Gc & February 1999 & $\begin{array}{l}51^{\circ} 31.00 \mathrm{~N} \\
03^{\circ} 19.00 \mathrm{E} \\
51^{\circ} 30.30 \mathrm{~N}\end{array}$ & - & 13 \\
\hline \multirow[t]{3}{*}{ Off-shore } & Oosthinder & $\mathrm{Oh}$ & October 1997 & $\begin{array}{l}02^{\circ} 38.32 \mathrm{E} \\
51^{\circ} 33.37 \mathrm{~N}\end{array}$ & 51 & 31 \\
\hline & Bligh Bank & Bli & February 1998 & $\begin{array}{l}02^{\circ} 44.16 \mathrm{E} \\
51^{\circ} 39.50 \mathrm{~N}\end{array}$ & 28 & 61 \\
\hline & Noordhinder & $\mathrm{Nh}$ & October 1998 & $02^{\circ} 36.14 \mathrm{E}$ & - & 46 \\
\hline Wadden Sea & Frisian Front & $\mathrm{FF}$ & December 1998 & $\begin{array}{c}53^{\circ} 30 \mathrm{~N} \\
4^{\circ} 00 \mathrm{E}\end{array}$ & 38 & 31 \\
\hline
\end{tabular}

zygous loci as the dependent variable and the sampling group as the independent variable.

\section{Results}

The total number of Pomatoschistus lozanoi and P. minutus analysed amounts to 409 and 637 specimens respectively (Table 2). A total of 14 loci were found suitable for cellulose acetate allozyme electrophoresis. The allele frequencies have been compiled in Appendix A ( $P$. minutus) and Appendix B (P. lozanoi).
An a priori exact test for allelic homogeneity (Raymond and Rousset, 1995) revealed no differentiation between $P$. lozanoi caught at the adjacent sampling stations GC-1 and 250 (Figure 1). They were subsequently pooled to increase the sample size and recoded as Gc.

\section{Genetic diversity}

The following loci were polymorphic in P. lozanoi: $A A T^{*}$, GPI- $A^{*}, G P I-B^{*}, L D H-B^{*}, L D H-C^{*}, M D H-B^{*}, P G M-1^{*}$ and $P G M-2^{*}$ (Appendix A). No samples of $P$. lozanoi deviated from Hardy-Weinberg proportions. In P. minutus, the loci 
Table 3 Genetic diversity of (a) P. lozanoi and (b) P. minutus expressed as unbiased expected heterozygosity $\left(H_{\mathrm{e}}\right)$, observed heterozygosity $\left(H_{\mathrm{O}}\right)$, percentage of polymorphic loci with the frequency of the most common allele not exceeding $0.99(P 0.99)$ and the average number of alleles per locus (AVG)

\begin{tabular}{|c|c|c|c|c|c|}
\hline Season & Sampling site & $\mathrm{H}_{\mathrm{e}}$ & $\mathrm{H}_{\mathrm{o}}$ & $P(0.99)$ & $A V G$ \\
\hline \multicolumn{6}{|l|}{ (a) P. lozanoi } \\
\hline \multirow{3}{*}{ Winter/spring } & D3 & $0.0977(0.1452)$ & $0.0735(0.1282)$ & 0.533 & 1.733 \\
\hline & Gc & $0.1037(0.2185)$ & $0.0708(0.1651)$ & 0.400 & 1.800 \\
\hline & Bli & $0.0925(0.1971)$ & $0.0761(0.1628)$ & 0.400 & 1.733 \\
\hline Frisian Front & $\mathrm{Ff}$ & $0.0506(0.1242)$ & $0.0367(0.0920)$ & 0.286 & 1.357 \\
\hline \multirow[t]{5}{*}{ Summer/autumn } & $\mathrm{Ze}$ & $0.0784(0.1726)$ & $0.0664(0.1442)$ & 0.400 & 1.667 \\
\hline & Ki10 & $0.0888(0.1880)$ & $0.0711(0.1322)$ & 0.400 & 1.600 \\
\hline & Os & $0.0768(0.1798)$ & $0.0540(0.1163)$ & 0.333 & 1.533 \\
\hline & $\mathrm{Nh}$ & $0.0895(0.2003)$ & $0.0710(0.1506)$ & 0.467 & 1.667 \\
\hline & $\mathrm{Oh}$ & $0.0851(0.2066)$ & $0.0692(0.1641)$ & 0.200 & 1.333 \\
\hline \multicolumn{6}{|l|}{ (b) P. minutus } \\
\hline \multirow[t]{5}{*}{ Winter/spring } & Bli & $0.1020(0.1830)$ & $0.0666(0.1101)$ & 0.357 & 1.64 \\
\hline & Ki2 & $0.0996(0.2098)$ & $0.0862(0.1792)$ & 0.214 & 1.64 \\
\hline & $\mathrm{Sb}$ & $0.1017(0.2041)$ & $0.1042(0.2204)$ & 0.286 & 1.50 \\
\hline & $\mathrm{Ra}$ & $0.1099(0.2075)$ & $0.0955(0.1885)$ & 0.429 & 1.71 \\
\hline & $\mathrm{FrF}$ & $0.1083(0.2120)$ & $0.0639(0.1134)$ & 0.357 & 1.64 \\
\hline \multirow[t]{5}{*}{ Autumn } & D10 & $0.0995(0.1845)$ & $0.0841(0.1599)$ & 0.357 & 2.07 \\
\hline & Ki10 & $0.1104(0.2103)$ & $0.0929(0.1679)$ & 0.286 & 2.14 \\
\hline & Oh & $0.1100(0.2079)$ & $0.0838(0.1683)$ & 0.429 & 1.86 \\
\hline & $\mathrm{Htw}$ & $0.0844(0.1670)$ & $0.0649(0.1204)$ & 0.357 & 1.57 \\
\hline & Os & $0.1114(0.2193)$ & $0.0861(0.1700)$ & 0.286 & 1.79 \\
\hline
\end{tabular}

Table 4 Single-locus $F_{\mathrm{ST}}$ values for $P$. minutus and P. lozanoi across all samples

\begin{tabular}{lcl}
\hline Locus & P. minutus & P. lozanoi \\
\hline$A A T^{*}$ & -0.0003 & -0.002 \\
$L D H-A^{*}$ & -0.004 & - \\
$L D H-B^{*}$ & 0.0071 & -0.010 \\
$L D H-C^{*}$ & 0.026 & 0.006 \\
GPI- $A^{*}$ & 0.006 & 0.042 \\
GPI- $B^{*}$ & -0.001 & -0.006 \\
$M D H-A^{*}$ & 0.009 & -0.005 \\
$M D H-B^{*}$ & - & 0.003 \\
$P G M-1^{*}$ & -0.004 & -0.014 \\
$P G M-2^{*}$ & 0.009 & 0.024 (all loci) \\
& & -0.003 (without $G P I-A^{*}$ )
\end{tabular}

$A A T^{*}, G P I-A^{*}, G P I-B^{*}, L D H-A^{*}, L D H-B^{*}, L D H-C^{*}, M D H-$ $A^{*}, P G M-1^{*}, P G M-2^{*}$ were polymorphic (Appendix B). Locus $L D H-C^{*}$ in $P$. minutus showed a significant heterozygote deficit across all samples with the exception of the samples from the Stroombank and 120. The other loci did not deviate significantly from Hardy-Weinberg proportions in any sample. In P. lozanoi, four cases of linkage disequilibrium were noticed and in P. minutus five cases were recorded out of a total of 91 comparisons, involving mainly the enzyme systems LDH, PGM and GPI. Observed and expected heterozygosity across all loci per sampling were similar across all samples within each species, with a high standard deviation (Table 3a and b). P. minutus had a higher degree of heterozygosity than P. lozanoi. P. lozanoi and P. minutus showed no significant differences in heterozygosity between sites along the Belgian coast (Kruskal-Wallis ANOVA: $P$. lozanoi: $P=0.457$; $P$. minutus: $P=0.900, \mathrm{NS})$.

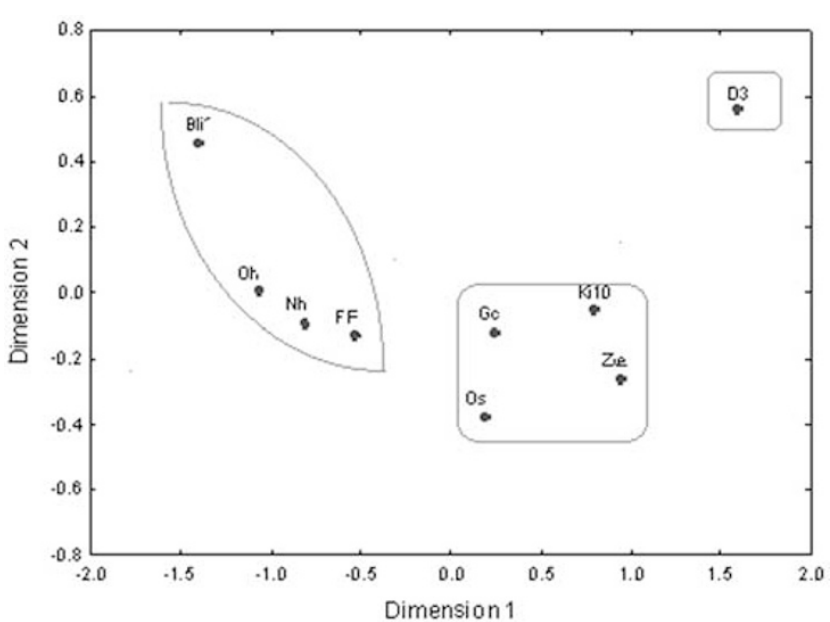

Figure 2 P. lozanoi: MDSA based on pairwise $F_{\mathrm{ST}}$ values (Weir and Cockherham, 1984) at locus GPI- $A^{*}$. Stress value $=0.0085$.

\section{Genetic differentiation}

$P$. minutus was differentiated between sampling sites at $L D H-C^{*}$, but this locus was excluded from the overall $F_{\mathrm{ST}}$ analysis due to the large deviations from HardyWeinberg proportions in most samples. No gradient in allele frequencies was observed at this locus. Only the pairwise $F_{\mathrm{ST}}$ value between Doel and the Frisian Front turned out to be significant. The multilocus $F_{\mathrm{ST}}$ value across all populations and loci (except $L D H-C^{*}$ ) for $P$. minutus amounted to 0.005 and was not significant (Table 4). MDSA did not reveal any geographical clustering, with or without $L D H-C^{*}$ included.

$P$. lozanoi showed significant pairwise differences in allele frequencies at the GPI- $A^{*}$ locus, differentiating the samples into three groups: an estuarine, a coastal and an offshore group (Figure 2). The Frisian Front grouped 
with the offshore samples from the Belgian coast. Singlelocus $F_{\mathrm{ST}}$ values were significant for GPI- $A^{*}$ only (Table 4 ). The multilocus $F_{\mathrm{ST}}$ value across all samples and all loci amounted to 0.024. When the GPI- $A^{*}$ locus was excluded from the analysis, no significant differentiation between the samples was observed anymore (multilocus $F_{\mathrm{ST}}=-0.003$ ).

\section{Clinal variation at locus $\mathrm{GPI}-A^{*}$ of the alleles ${ }^{100} \mathrm{GPI}-A^{*}$} and ${ }^{113} \mathrm{GPI}-A^{*}$ in $P$. lozanoi

Locus GPI- $A^{*}$ has three alleles that occur in both species, namely ${ }^{90} G P I-A^{*},{ }^{100} G P I-A^{*}$ and ${ }^{113} G P I-A^{*}$ (Appendices A and B). Allele ${ }^{90} G P I-A^{*}$ was rarely recorded in either species. $P$. minutus shows limited polymorphism at GPI$A^{*}$, with a frequency of ${ }^{100} \mathrm{GPI}-A^{*}$ above 0.95 . P. lozanoi on the contrary shows a much larger degree of polymorphism at this locus and a clinal change in allele frequencies of ${ }^{100} \mathrm{GPI}-A^{*}$ and ${ }^{113} \mathrm{GPI}-A^{*}$. The frequency of allele ${ }^{100} \mathrm{GPI}-$ $A^{*}$ in $P$. lozanoi increases with distance from the shore, with the lowest frequencies in Doel and the highest at the Hinderbanken (Figure 3). A Spearman rank correlation showed a significant relationship between coastal distance and the frequency of ${ }^{100} \mathrm{GPI}-A^{*}(P<0.05)$. In Doel, no ${ }^{100} G P I-A^{*} /{ }^{100} G P I-A^{*}$ homozygotes and only few ${ }^{100} \mathrm{GPI}-A^{*} /{ }^{113} \mathrm{GPI}-A^{*}$ heterozygotes were recorded. In $P$. minutus, this locus showed minimal polymorphism and no gradient in allele frequencies was observed.

\section{Discussion}

\section{Lack of small-scale genetic variation in relation to environmental heterogeneity}

Our study did not find any differences in the level of genetic variation in $P$. minutus and P. lozanoi, which could be linked to the degree of heterogeneity of the habitats where the samples were collected. We can confirm the lower degree of genetic variation in P. lozanoi compared to $P$. minutus. The fact that the level of heterozygosity is lower in all P. lozanoi samples than in P. minutus has been linked to the degree of heterogeneity of the environ ment in which both species prefer to live (Wallis and

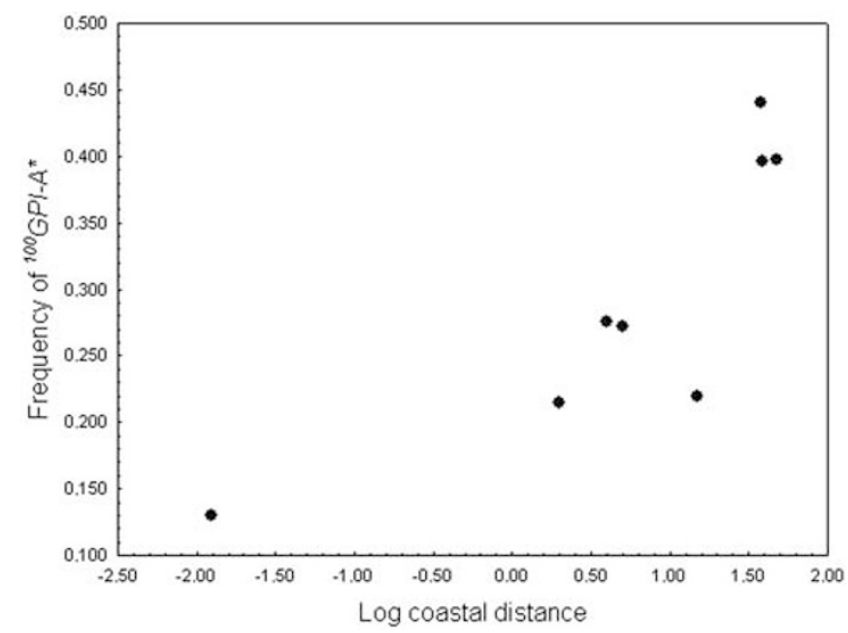

Figure 3 P. lozanoi: frequency of ${ }^{100} \mathrm{GPI}-A^{*}$ in function of coastal distance.
Beardmore, 1984b). However, we cannot support the hypothesis that this difference may be due to their occurrence in habitats subject to a different degree of heterogeneity, because $P$. minutus and $P$. lozanoi occur sympatrically throughout the whole sampling range. Sorice and Caputo (1999) noticed that highly polymorphic Mediterranean goby species were also karyologically highly variable and suggested genomic constraints in chromosome variation as an alternative hypothesis for explaining different levels of polymorphism between goby species. We found no evidence for increased levels of heterozygosity for individuals occurring in estuarine (heterogeneous) vs marine (more stable) habitats in either species.

\section{Small-scale population differentiation in Pomatoschistus} sp or natural selection on specific loci?

GPI- $A^{*}$ in $P$. lozanoi: The differentiation between the coastal, estuarine and offshore samples in $P$. lozanoi (Figure 2) is entirely due to the differences at a single locus, GPI- $A^{*}$. Genetic drift and gene flow should affect all polymorphic loci similarly, while natural selection acts on specific loci. The complete lack of genetic differentiation between samples at all other loci, together with the extended pelagic larval phase in Pomatoschistus sp, suggests extensive gene flow throughout the area. This is confirmed by Pampoulie et al (2004), who found little genetic differentiation among sand goby samples from the BCS, suggesting one single breeding unit off the Belgian coast, and another breeding unit in the Oosterschelde. Hence, the genetic differences between the $P$. lozanoi samples are probably maintained by some form of natural selection rather than by limited gene flow. The fact that the reference sample from the Frisian Front, an offshore location, groups together with the offshore Belgian samples based on its allele frequencies at locus GPI-A* (Figure 2) supports the hypothesis that some environmental factor might be responsible for the observed allele frequencies. Christiansen and Frydenberg (1974) reported a similar cline in allele frequencies at two unlinked loci in eelpout and suggested that these clines were maintained by selective pressure. Levene's model (1953) of balancing selection at a two-allele locus states that both alleles may be maintained in the population by natural selection when selection pressure varies between niches, resulting in a higher fitness of the alternative homozygote genotypes in the various habitats. If we apply this to the lozano's gobies investigated on the BCS and the Schelde estuary, this would mean that those fish carrying allele ${ }^{100} \mathrm{GPI}-A^{*}$ may perform less well in estuarine conditions, whereas individuals possessing allele ${ }^{113} \mathrm{GPI}-A^{*}$ might be less adapted to the marine environment.

Although a correlation between allele frequencies at the GPI* loci and temperature in fish (including gobies) and other organisms has been reported (Al-Hassan et al, 1987; Zera, 1987), there was no such evidence in this study. The sites were sampled in different seasons (Table 2), yet the samples from the respective habitats (estuarine, coastal and marine) grouped together in the MDSA. Oxygen concentration at the sampling sites (data not shown) did not reveal any trend that might be linked 
to the differences at GPI- $A^{*}$. Salinity, which increases with increasing distance from the Schelde estuary, yielded a weak but significantly positive linear correlation with the frequency of ${ }^{100} G P I-A^{*}\left(R^{2}=0.52, P<0.04\right)$. Koehn et al (1980) demonstrated an association between allele frequencies at the $L A P^{*}$ locus in Mytilus edulis and a salinity gradient. It is tempting to point to the salinity gradient for explaining the observed differences at GPI$A^{*}$ but any other factor correlating with distance to the coast would show a similar correlation. For example, the Schelde estuary is heavily polluted while the level of pollution decreases towards the offshore areas; the water flowing through the English Channel towards the Southern Bight represents relatively clean Atlantic water. De Wolf et al (2001) reported allozymatic differences at the esterase locus between samples of Littorina littorea in the Schelde estuary and adjacent areas, and suggested either salinity or anthropogenic effects as agents responsible for the differentiation. A number of studies have revealed differential mortality of distinct genotypes when exposed to heavy metals, suggesting they could be useful markers for assessing levels of pollution (BenShlomo and Nevo, 1988). Nevo et al (1984) and Newman and Jagoe (1998) found evidence for an allele shift at the $G P I^{*}$ loci in shrimps and fish respectively, when exposed to mercury. However, in order to prove an association between the observed GPI- $A^{*}$ genotypes and the level of pollution, detailed biochemical experiments would be required.

$L D H-C^{*}$ in $P$. minutus: $L D H-C^{*}$ showed a consistent heterozygote deficit across almost all $P$. minutus samples. Such a deficit might be attributed to scoring errors, null alleles, selection against heterozygotes, assortative mating or the Wahlund effect. Scoring error is ruled out because a very distinct three-allele-polymorphism was recorded at this locus using CAGE, contrary to starch gel electrophoresis (Wallis and Beardmore, 1984a, b; Stefanni et al, 2003). If the heterozygote deficit were due to the mixing of subpopulations, we would have expected a similar effect at the other polymorphic loci; this is not the case. Null alleles may be another explanation (Richardson et al, 1986), but this should be obvious from the pattern and the intensity of the bands, and we found no evidence for it. Selective mortality of heterozygotes has often been invoked for the heterozygote deficit observed in marine organisms (Zouros and Foltz, 1984; Kotoulas et al, 1995). Evidence exists that alleles of the $L D H^{*}$ loci are subject to natural selection (Mitton and Koehn, 1975; DiMichele et al, 1991). However, detailed biochemical experiments would be needed to ascertain whether the products of the various alleles perform differently.

\section{Acknowledgements}

We are indebted to M Fonds (NIOZ), the crew of the RV 'Belgica', the Fisheries Department in Ostend and A Cattrijsse and colleagues from the Marine Biology Section at Ghent University for providing samples. The Management Unit for the Mathematical Models of the North Sea (MUMM) is acknowledged for providing data on oxygen and salinity. We are indebted to G Nævdal, JP Pujolar and two anonymous referees for valuable comments on an earlier draft of the manuscript. EG was supported by the Institute for Scientific and Technological Research (IWT) and by a Marie Curie Fellowship of the European Community Contract No. EVK3-CT-2000-57129 at Bergen Advanced Training Site in Marine Ecology (BATMARE), University of Bergen, Norway. Research was funded by the Federal Services of Scientific and Technological Affairs (OSCT Contract No. $\mathrm{MN} / \mathrm{DD} / 42$ )

\section{References}

Al-Hassan AJ, Webb CJ, Giama M, Miller PJ (1987). Phosphoglucose isomerase polymorphism in the common goby, Pomatoschistus microps (Krøyer) (Teleostei: Gobbidae), around the British Isles. J Fish Biol 30: 281-298.

Ballard JWO, Kreitman M (1995). Is mitochondrial DNA a strictly neutral marker?. TREE 10: 485-488.

Belkhir K, Borsa P, Chikhi L, Raufaste N, Bonhomme F (2001). GENETIX 4.02, logiciel sous Windows TM pour la génétique des populations. Laboratoire Génome, Populations, Interactions CNRS UMR 5000. Université de Montpellier II, Montpellier, France.

Ben-Shlomo R, Nevo E (1988). Isozyme polymorphism as monitoring of marine environments: the interactive effect of cadmium and mercury pollution on the shrimp, Palaemon elegans. Mar Pollut Bull 19: 314-317.

Christiansen FB, Frydenberg O (1974). Geographical patterns of four polymorphisms in Zoarces viviparus as evidence of selection. Genetics 77: 765-770.

Claridge PN, Hardisty MW, Potter IC, Williams CW (1985). Abundance, life history and ligulosis in the gobies (Teleostei) of the inner Severn estuary. J Mar Biol Assoc UK 65: 951-968.

De Wolf H, Jordaens K, Reusens E, Blust R, Backeljau T (2001). Esterase variation in the periwinkle Littorina littorea, along the western and eastern Scheldt estuarium. Mar Environ Res 20: 373-382.

DiMichele L, Paynter KT, Powers DA (1991). Evidence of lactate dehydrogenase-B allozyme effects in the teleost, Fundulus heteroclitus. Science 253: 898-900.

Eanes WF (2002). Analysis of selection on enzyme polymorphisms. Annu Rev Ecol Syst 30: 301-326.

Fonds M (1973). Sand gobies in the Dutch Wadden Sea (Pomatoschistus, Gobiidae, Pisces). Neth J Sea Res 6: 417-473.

Hamerlynck O, Cattrijsse A (1994). The food of Pomatoschistus minutus (Pisces, Gobiidae) in Belgian coastal waters, and a comparison with the food of its potential competitor $P$. lozanoi. J Fish Biol 44: 753-771.

Hebert PDN, Beaton MJ (1989). Methodologies for Allozyme Analysis Using Cellulose Acetate Electrophoresis: A Practical Handbook. Helena Laboratories Inc.: Beaumont, TX, USA.

Hey J (1999). The neutralist, the fly and the selectionist. TREE 14: $35-38$

Jones A, Walker D, Lindström K, Kvarnemo C, Avise JC (2001). Surprising similarity of sneaking rates and genetic mating patterns in two populations of sand goby experiencing disparate sexual selection regimes. Mol Ecol 10: 461-469.

Kimura M (1979). The neutral theory of molecular evolution. Sci Am 241: 98-125.

Koehn RK, Newell RIE, Immermann F (1980). Maintenance of an aminopeptidase allele frequency cline by natural selection. Proc Natl Acad Sci USA 77: 5385-5389.

Koehn RK, Zera AJ, Hall JC (1983). Enzyme polymorphism and natural selection. In: Nei M, Koehn RK (eds) Evolution of Genes and Proteins. Sinauer Associates: Sunderland, MA, pp $115-136$.

Kotoulas G, Bonhomme F, Borsa P (1995). Genetic structure of the common sole Solea vulgaris at different geographic scales. Mar Biol 122: 361-375.

Levene H (1953). Genetic equilibrium when more than one ecological niche is available. Am Nat 87: 331-333. 
Maes J, Van Damme PA, Taillieu A, Ollevier F (1998) Fish communities along an oxygen-poor salinity gradient (Zeeschelde estuary, Belgium). J Fish Biol 52: 534-546.

Miller PJ (1986). Gobiidae. In: Whitehead PJP, Bauchot M-L, Hureau JC, Nielson J, and Tortonese E. (eds) Fishes of the North-eastern Atlantic and Mediterranean. UNESCO: Paris, pp 1019-1085.

Mitton JB, Koehn RK (1975). Genetic organization and adaptive response of allozymes to ecological variables in Fundulus heteroclitus. Genetics 79: 97-111.

Nei M (1978). Estimation of average heterozygosity and genetic distance from a small number of individuals. Genetics 89 583-590.

Nevo E, Ben-Shlomo R, Lavie B (1984). Mercury selection of allozymes in marine organisms: prediction and verification in nature. Proc Natl Acad Sci USA 81: 1258-1259.

Newman MC, Jagoe RH (1998). Allozymes reflect the population-level effect of mercury: simulations of the mosquitofish (Gambusia holbrooki Girard) GPI-2 response. Ecotoxicology 7: 141-150.

Nihoul J, Hecq JH (1984). Influence of the residual circulation on the physico-chemical characteristics of water masses and the dynamics of ecosystems in the Belgian coastal zone. Cont Shelf Res 3: 167-174.

Pampoulie C, Rosecchi E, Bouchereau JL, Crivelli AJ (1999). Life history traits of Pomatoschistus minutus in the Rhône delta, France. J Fish Biol 55: 892-896.

Pampoulie C, Gysels ES, Maes GE, Hellemans B, Leentjes V, Jones AG et al (2004). Evidence for fine-scale genetic structure and estuarine colonisation in a potential high gene flow marine goby (Pomatoschistus minutus). Heredity 92: 434-445.
Powell J (1971). Genetic polymorphisms in varied environments. Science 174: 1035-1036.

Raymond M, Rousset F (1995). GENEPOP: population genetics software for exact tests and eucumenicism. J Heredity 86: 248-249.

Richardson BJ, Baverstock PR, Adams M (1986). Allozyme Electrophoresis: A Handbook for Animal Systematics and Population Studies. Academic Press Ltd: London.

Shaklee JB, Allendorf FW, Morizot DC, Whitt GS (1990). Gene nomenclature for protein-coding loci in fish. Trans Am Fish Soc 119: 2-15.

Sorice M, Caputo V (1999). Genetic variation in seven goby sepcies (Perciformes: Gobiidae) assessed by electrophoresis and taxonomic inference. Mar Biol 134: 327-333.

Stefanni S, Gysels ES, Volckaert FAM, Miller PJ (2003). Allozyme variation and genetic divergence in the sand goby, Pomatoschistus minutus (Teleostei: Gobiidae). I Mar Biol Assoc UK 83: 1143-1149.

Wallis GP, Beardmore JA (1984a). Genetic variation and environmental heterogeneity in some closely related goby species. Genetica 62: 223-237.

Wallis GP, Beardmore JA (1984b). An electrophoretic study of the systematic relationships of some closely related goby species (Pisces, Gobiidae). Biol J Linn Soc 22: 107-123.

Weir BS, Cockerham CC (1984). Estimating F-statistics for the analysis of population structure. Evolution 38: 1358-1370.

Zera AJ (1987). Temperature-dependent kinetic variation among phosphoglucose isomerase allozymes from the wing-polymorphic Water Strider, Limnoporus canaliculatus. Mol Biol Evol 4: 266-285.

Zouros E, Foltz DW (1984). Possible explanations of heterozygote deficiency in bivalve molluscs. Malacologia 25: 583-591. 